\title{
Effects of the DGAT1 polymorphism on test-day milk production traits throughout lactation
}

\author{
H. Bovenhuis, ${ }^{* 1}$ M. H. P. W. Visker, ${ }^{*}$ H. J. F. van Valenberg,† A. J. Buitenhuis, $\ddagger$ and J. A. M. van Arendonk* \\ ${ }^{*}$ Animal Breeding and Genomics Centre, Wageningen University, PO Box 338, 6700 AH Wageningen, the Netherlands \\ †Dairy Science and Technology Group, Wageningen University, PO Box 17, 6700 AA, Wageningen, the Netherlands \\ $\neq$ Center for Quantitative Genetics and Genomics, Department of Molecular Biology and Genetics, Aarhus University, PO Box 50, \\ DK-8830 Tjele, Denmark
}

\section{ABSTRACT}

Several studies have shown that the diacylglycerol Oacyltransferase 1 (DGAT1) K232A polymorphism has a major effect on milk production traits. It is less clear how effects of $D G A T 1$ on milk production traits change throughout lactation, if dominance effects of DGAT1 are relevant, and whether DGAT1 also affects lactose content, lactose yield, and total energy output in milk. Results from this study, using test-day records of 3 subsequent parities of around 1,800 cows, confirm previously reported effects of the DGAT1 polymorphism on milk, fat, and protein yield, as well as fat and protein content. In addition, we found significant effects of the $D G A T 1$ polymorphism on lactose content and lactose yield. No significant effects on somatic cell score were detected. The effect of DGAT1 on total energy excreted in milk was only significant in parity 1 and is mainly due to a higher energy output in milk of heterozygous cows. Significant but relatively small dominance effects of DGAT1 on fat content and yield were detected, which are of little practical relevance. Significant DGAT1 by lactation stage interaction was detected for milk yield, lactose yield, fat content, and protein content, indicating that the effect of the DGAT1 polymorphism changes during lactation. In general, the DGAT1 effect shows a large increase during early lactation (from the start of lactation to d 50 to 150) and tends to decrease later in lactation. No DGAT1 by lactation stage interaction for fat yield was observed. Similar to DGAT1, effects of other genes also might vary throughout lactation and, therefore, using longitudinal models is recommended.

Key words: DGAT1, lactation stage, lactose, energy output

Received March 13, 2015.

Accepted May 20, 2015.

${ }^{1}$ Corresponding author: henk.bovenhuis@wur.nl

\section{INTRODUCTION}

Since the identification of the diacylglycerol O-acyltransferase 1 (DGAT1) K232A polymorphism by Grisart et al. (2002) and Winter et al. (2002), many studies have investigated associations between this polymorphism and milk production traits (e.g., Spelman et al., 2002; Thaller et al., 2003; Weller et al., 2003; Gautier et al., 2007). Although the magnitude of the estimated effects reported in these studies differ, they consistently show that the DGAT1 K232A polymorphism has a major effect on milk production traits: the $\mathrm{K}$ allele is associated with a higher fat content, protein content, and fat yield, but lower milk and protein yields. Because of the strong negative relationship between lactose and fat content in milk across species (Fox, 2009), it is hypothesized that the DGAT1 polymorphism also affects lactose content. To our knowledge, the effects of the DGAT1 K232A polymorphism on lactose yield or content have not been quantified previously.

Most associations between the DGAT1 K232A polymorphism and milk production traits are based on 305-d daughter yield deviations (Grisart et al., 2002; Winter et al., 2002; Spelman et al., 2002; Thaller et al., 2003; Weller et al., 2003; Gautier et al., 2007). Kuehn et al. (2007) detected significant dominance effects of the DGAT1 polymorphism on milk fat content, and recent studies by Strucken et al. (2011) and Szyda et al. (2014) suggest that effects of DGAT1 are not constant throughout lactation. Daughter yield deviations do not allow estimating dominance effects, and changes in gene effects throughout lactation remain unnoticed when effects are estimated based on 305-d production records. Consequently, dominant gene action of DGAT1 has not been confirmed and the ambiguity on how effects of DGAT1 on milk production traits change throughout lactation has not been resolved. Analysis based on testday records throughout lactation would enable to study both phenomena.

Diacylglycerol O-acyltransferase 1 mediates the final step in triglyceride synthesis and is expressed in the 
small intestine, liver, adipose tissues, and the mammary gland (DeVita and Pinto, 2013; Muise et al., 2014). The pharmaceutical industry has a great interest in $D G A T 1$ as a target for human metabolic diseases. This interest was especially fueled by a study on DGAT1 knockout mice that showed several beneficial metabolic phenotypes, including resistance to diet-induced obesity (DeVita and Pinto, 2013). Therefore, one might hypothesize an effect of DGAT1 on traits other than milk production. Besides a direct effect of the DGAT1 polymorphism on the cow metabolism, the strong effect of the DGAT1 polymorphism on milk production traits might indirectly affect total energy output in milk and, consequently, the energy balance of cows. As a negative energy balance during early lactation of high-yielding dairy cows can result in metabolic and reproductive disorders, it is of interest to study the effect of the DGAT1 polymorphism on total energy output in milk. The aim of the current study was to estimate the additive and dominance effects of the DGAT1 polymorphism on milk production traits, including lactose and total energy output in milk, throughout the lactation in parity 1,2, and 3 using test-day milk production records.

\section{MATERIALS AND METHODS}

\section{Animals}

Test day records from parity 1, 2, and 3 of cows involved in the Dutch Milk Genomics Initiative were retrieved from the database of the herd book (CRV, Arnhem, the Netherlands). The Dutch Milk Genomics Initiative comprised 2,000 first-lactation Dutch Holstein-Friesian cows from 398 herds throughout the Netherlands. At least 3 cows per herd were sampled. All cows were housed in loose housing systems, fed according to standard practice, and milked twice a day. Further details about the experimental design can be found in Stoop et al. (2008). Only animals that had been genotyped for the DGAT1 K232A polymorphism were included in our study.

\section{Traits}

Fat, protein, and lactose content were based on infrared spectroscopy measurements using a MilkoScan FT6000 (Foss Electric, Hillerød, Denmark) at the Milk Control Station (Qlip, Zutphen, the Netherlands). Somatic cell count was determined using a Fossomatic 5000 (Foss Electric) at the Milk Control Station. Somatic cell counts were log-transformed (base 2) to obtain SCS. Fat, protein, and lactose yields per test day were calculated by multiplying the respective contents with test-day milk yield. Total energy output in milk (TEM) per test day was calculated by multiplying the net energy for milk with test-day milk yield, where net energy for milk was calculated as described by Tyrrell and Reid (1965):

$$
\begin{gathered}
\text { TEM }(\mathrm{MJ})=\text { net energy for milk }(\mathrm{MJ} / \mathrm{kg}) \\
\times \mathrm{kg} \text { of milk }=[0.384(\% \text { fat })+0.223(\% \text { protein }) \\
+0.199(\% \text { lactose })-0.108] \times \mathrm{kg} \text { of milk. }
\end{gathered}
$$

\section{Genotypes}

Genotypes for the DGAT1 K232A polymorphism were obtained with a Taqman allelic discrimination assay in an Applied Biosystems 7500 Real-Time PCR System (Applied Biosystems, Foster City, CA) as described by Schennink et al. (2007).

\section{Statistical Analysis}

Test-day records from parity 1,2 , and 3 were separately analyzed using the following repeatability model:

$$
\begin{aligned}
& \mathrm{y}_{\mathrm{ijklmno}}=\mu+\operatorname{season}_{\mathrm{i}}+\text { scode }_{\mathrm{j}}+\text { lact }_{\mathrm{k}}+D G A T 1_{1} \\
& +\beta_{1} \mathrm{ca}_{\mathrm{ijkl} \text { mno }}+\operatorname{animal}_{\mathrm{m}}+\mathrm{HTM}_{\mathrm{n}}+\mathrm{ep}_{\mathrm{o}}+\mathrm{e}_{\mathrm{ijklmno}}
\end{aligned}
$$

where $\mathrm{y}_{\mathrm{ijklmno}}$ is a test-day observation; $\mu$ is the overall mean of the trait; season ${ }_{i}$ is the fixed effect of the ith class of calving season (4 classes: August-October, November-January, February-April, and May-July); scode $_{j}$ is the fixed effect accounting for possible differences in genetic level between proven bull daughters and young bull daughters; lact $\mathrm{k}_{\mathrm{k}}$ is the fixed effect of lactation stage (26 classes of $15 \mathrm{~d}$, with class 1 from 0 to $15 \mathrm{~d}$ and class 26 from 375 to $390 \mathrm{~d}$ in lactation); $D G A T 1_{1}$ is the fixed effect of DGAT1 K232A genotype (AA, AK, or KK alleles); $\mathrm{ca}_{\mathrm{ijklmno}}$ is a covariate describing the effect of age at first, second, or third calving; animal $_{\mathrm{m}}$ is the random additive genetic effect of animal $\mathrm{m} ; \mathrm{HTM}_{\mathrm{n}}$ is the random effect of the nth herd-testmonth; $\mathrm{ep}_{\mathrm{o}}$ is the permanent environmental effect of cow o; and $\mathrm{e}_{\mathrm{ijk} k \mathrm{mno}}$ is the random residual. Animal effects were assumed distributed as $N\left(\mathbf{0}, \mathbf{A} \sigma_{a}^{2}\right)$, herd-test-month effects as $N\left(\mathbf{0}, \mathbf{I} \sigma_{\mathrm{HTM}}^{2}\right)$, permanent environmental effects as $N\left(\mathbf{0}, \mathbf{I} \sigma_{\text {ep }}^{2}\right)$, and residuals as $N\left(\mathbf{0}, \mathbf{I} \sigma_{e}^{2}\right)$, where $\mathbf{A}$ is the additive genetic relationships matrix and $\mathbf{I}$ the identity matrix. The A matrix was constructed based on 26,300 individuals.

Dominant mode of gene action was tested using the option !CONTRAST in ASReml v3.0 (Gilmour et al., 
Table 1. Descriptive statistics for test day records of 1,829 Dutch Holstein Friesian cows in parity 1, 1,578 cows in parity 2 , and 1,204 cows in parity 3

\begin{tabular}{|c|c|c|c|c|c|c|c|c|c|}
\hline \multirow[b]{2}{*}{ Item } & \multicolumn{3}{|c|}{ Parity 1} & \multicolumn{3}{|c|}{ Parity 2} & \multicolumn{3}{|c|}{ Parity 3} \\
\hline & $\mathrm{n}$ & Mean & $\mathrm{SD}$ & $\mathrm{n}$ & Mean & $\mathrm{SD}$ & $\mathrm{n}$ & Mean & $\mathrm{SD}$ \\
\hline Protein yield (kg) & 19,547 & 0.85 & 0.17 & 15,752 & 1.02 & 0.24 & 11,284 & 1.07 & 0.28 \\
\hline Lactose yield (kg) & 19,336 & 1.15 & 0.26 & 14,510 & 1.31 & 0.39 & 11,281 & 1.39 & 0.45 \\
\hline Fat $(\%)$ & 19,547 & 4.36 & 0.65 & 15,752 & 4.37 & 0.72 & 11,284 & 4.34 & 0.73 \\
\hline $\mathrm{SCS}^{1}$ & 18,240 & 6.00 & 1.49 & 14,908 & 6.33 & 1.68 & 10,813 & 6.79 & 1.76 \\
\hline $\mathrm{TEM}^{2}(\mathrm{MJ})$ & 19,336 & 79.8 & 15.5 & 14,510 & 92.8 & 23.7 & 11,281 & 98.5 & 27.7 \\
\hline
\end{tabular}

${ }^{1} \log _{2}(\mathrm{SCC})$.

${ }^{2} \mathrm{TEM}($ total energy output in milk $)=\mathrm{kg}$ of milk $\times[0.384(\%$ fat $)+0.223(\%$ protein $)+0.199(\%$ lactose $)-0.108]$.

2009). Dominance effects were defined as the deviation of the AK genotype effect from the average of KK and AA genotype effects. To investigate if the effect of the $D G A T 1$ polymorphism changed during lactation we tested for a $D G A T 1$ by lactation stage interaction using the following model:

$$
\begin{gathered}
\mathrm{y}_{\mathrm{ijklmno}}=\mu+\text { season }_{\mathrm{i}}+\text { scode }_{\mathrm{j}}+\text { lact }_{\mathrm{k}}+D G A T 1_{1} \\
+\left(D G A T 1 \times \text { lact }_{\mathrm{kl}}+\beta_{1} \mathrm{ca}_{\mathrm{ijklmno}}+\operatorname{animal}_{\mathrm{m}}\right. \\
+\mathrm{HTM}_{\mathrm{n}}+\mathrm{ep}_{\mathrm{o}}+\mathrm{e}_{\mathrm{ijklmno}}
\end{gathered}
$$

where effects are as defined for model [2] and (DGAT1 $\times$ lact $)_{\mathrm{kl}}$ is the $D G A T 1$ by lactation stage interaction.

\section{RESULTS}

\section{Descriptive Statistics}

Test-day records were available for 1,829 cows in parity 1 . For a subset of 1,578 cows, parity 2 test-day records were also available, and for 1,204 of the cows, parity 3 test-day records were available for analysis. The frequency of the DGAT1 K allele was 0.40 in parity 1 and 0.41 in parities 2 and 3 . No significant deviation of the DGAT1 genotype frequencies from Hardy-Weinberg equilibrium were noted in any of the parities. Table 1 shows the descriptive statistics of the test-day records. The number of test-day records per cow ranged from 8.9 for SCS in parity 3 to 10.7 for milk yield in parity 1 . The average milk production per day increased from $24.6 \mathrm{~kg}$ in parity 1 to $29.0 \mathrm{~kg}$ in parity 2 and, subsequently, to $30.8 \mathrm{~kg}$ in parity 3 . For fat, protein, and lactose yield, similar increases in means with increasing parity number were observed. Mean fat and protein percent increased from parity 1 to 2 , but was slightly lower in parity 3 as compared with parity 2. Lactose percent decreased from parity 1 to 2 and, subsequently, to parity 3, whereas SCS and TEM increased. Standard deviations for all traits increased with increasing parity number.

\section{Lactation-Average DGAT1 Effects}

The DGAT1 polymorphism showed highly significant effects on milk production traits (Table 2). The K allele was associated with lower milk, protein, and lactose yields, and higher fat yield and fat, protein, and lactose percent. No significant effect of the DGAT1 polymorphism on SCS was detected. The effect of DGAT1 on TEM was only significant in parity $1(P<0.05)$, where the AK genotype was associated with higher TEM. This effect would not be significant when adjusting for multiple testing.

Additive genetic effects for yield traits (kilograms of milk, fat, protein, and lactose) in parity 2 were about $30 \%$ higher than in parity 1 (Table 2). For fat and protein percent, this was about $18 \%$. The additive effect of DGAT1 on lactose percent was twice as large in parity 2 as in parity 1 , and the effect further increased in parity 3. For most other traits, the effects of DGAT1 in parity 3 tended to be slightly smaller than in parity 2. When expressed in phenotypic standard deviations (as given in Table 1), effects on fat and protein percent in parities 1,2 , and 3 were similar.

\section{Dominance}

Significant dominance effects of DGAT1 on fat percent were detected in all 3 parities (Table 3 ). The estimated dominance effect for fat percent was about 0.05. For fat yield, a significant dominance effect was detected in parity 1 only. For TEM, a significant dominance effect was detected in parity 1 , where TEM was 
highest for AK cows. No significant dominance effects of the DGAT1 polymorphism were detected for the other traits.

\section{DGAT1 by Lactation Stage Interaction}

Significant DGAT1 by lactation stage interactions were detected for milk yield, lactose yield, and fat and protein percent in all 3 parities (Table 3 ). This is illustrated in Figure 1, which shows the estimates of the $(D G A T 1 \times$ Lact $)$ interaction term for parity 1 from a model without the main effects of $D G A T 1_{1}$ and lact $\mathrm{k}_{\mathrm{k}}$ and the effect of the AK genotype in lactation stage 13 fixed at 0 . These estimates have been used to calculate additive genetic effects at different stages of lactation, which were defined as half the difference between the KK and AA genotypic effects. Figure 2 shows the additive effects for parities 1 and 2. Results for parity 3 are not shown because these were very similar to results for parity 2 .

The difference in milk yield between the 3 genotypes was small during the first $30 \mathrm{~d}$ of lactation (Figure 1 and 2). In parity 1 , an additive effect of around -1.6 $\mathrm{kg}$ of milk was reached at $\mathrm{d} 100$ in lactation and stayed approximately constant at this level until d 200 in lactation. Later in lactation $(>200 \mathrm{~d})$ the additive effect decreased until about $-1 \mathrm{~kg}$ at d 300 (Figure 2). For parity 2 and 3 , a similar pattern was observed, but differences between KK and AA genotypes were larger and the maximum difference was reached earlier in lactation (i.e., around $70 \mathrm{~d}$ in lactation). For lactation stages $>300 \mathrm{~d}$, larger fluctuations in the estimates were observed due to smaller numbers of observations.

Interestingly, no evidence was observed for a DGAT1 by lactation stage interaction for fat yield (Table 3 ). Figure 2 shows that the additive effect of DGAT1 on fat yield was rather constant during the lactation. In parity 1 , a significant dominance effect was detected for fat yield, but also the dominance effect was constant throughout lactation (Figure 1). There was a highly significant $D G A T 1$ by lactation stage interaction on fat percent. At the start of the lactation $(<30 \mathrm{~d})$ the difference in fat percent between the KK and AA genotypes was approximately half of that in mid and late lactation (>150 d; Figure 2).

Significant $D G A T 1$ by lactation stage interactions for protein yield were found in parities 1 and 3. Similar to milk yield, there was a tendency of the DGAT1 effect to increase during early lactation $(<100 \mathrm{~d})$ and to decrease later in lactation (Figure 2). For protein percent, a highly significant DGAT1 by lactation stage interaction was noted, which showed a similar pattern as was observed for fat percent (Figure 2). The difference between the KK and AA genotypes was almost 
absent in early lactation $(<20 \mathrm{~d})$ and increased until about $150 \mathrm{~d}$ in lactation with a tendency to decrease later in lactation.

The DGAT1 by lactation stage interactions for lactose yield was similar to that for milk yield. In parity 1, no significant DGAT1 by lactation stage interaction was seen for lactose content, but in parity 2 and 3 the effect of DGAT1 on lactose content increased with lactation stage (Table 3 and Figure 2).

\section{DISCUSSION}

Results from our study confirmed previously reported effects of the DGAT1 polymorphism on milk production traits. In addition, we found significant effects on lactose content and lactose yield but no significant effects on SCS. A significant effect on total energy excreted in milk was detected only in parity 1 . In all 3 parities, significant DGAT1 by lactation stage interactions were detected for milk yield, lactose yield, fat content, and protein content, indicating that the effect of the $D G A T 1$ polymorphism changes throughout lactation. Dominance effects were detected for fat content and for fat yield and TEM in parity 1 only.

\section{Literature}

Several studies have reported on the effects of the DGAT1 polymorphism on milk production traits. Most of these studies estimated allele substitution effects using 305-d daughter yield deviations, which are often based on multiple parities. (e.g., Grisart et al., 2002; Winter et al., 2002; Spelman et al., 2002; Thaller et al., 2003; Weller et al., 2003; Gautier et al., 2007). This complicates comparing estimates obtained in different studies. The effects estimated in our study translate into a difference between $\mathrm{AA}$ and $\mathrm{KK}$ genotypes on a $305-\mathrm{d}$ base of $774 \mathrm{~kg}$ of milk, $-26.2 \mathrm{~kg}$ of fat, and 13.6 $\mathrm{kg}$ of protein in parity $1,1,042 \mathrm{~kg}$ of milk, $-35.8 \mathrm{~kg}$ of fat, and $18.0 \mathrm{~kg}$ of protein in parity 2 , and $1,028 \mathrm{~kg}$ of milk, $-37.2 \mathrm{~kg}$ of fat, and $16.4 \mathrm{~kg}$ of protein in parity 3 . These results are in line with estimates by Grisart et al. (2002) and Gautier et al. (2007), but are considerably larger than estimates reported by some other studies (e.g., Spelman et al., 2002; Berry et al., 2010). Spelman et al. (2002) indicated that DGAT1 effects in Dutch Holsteins and New Zealand Holsteins were similar when expressed in genetic standard deviations and, therefore, part of the differences in estimates might be attributed to scaling. In the current study, we found that effects of $D G A T 1$ were larger in parity 2 and 3 as compared with parity 1, which confirms results in German Holsteins (Thaller et al., 2003). When expressed in phenotypic standard deviations, effects in parities 1, 2, and 3 were 

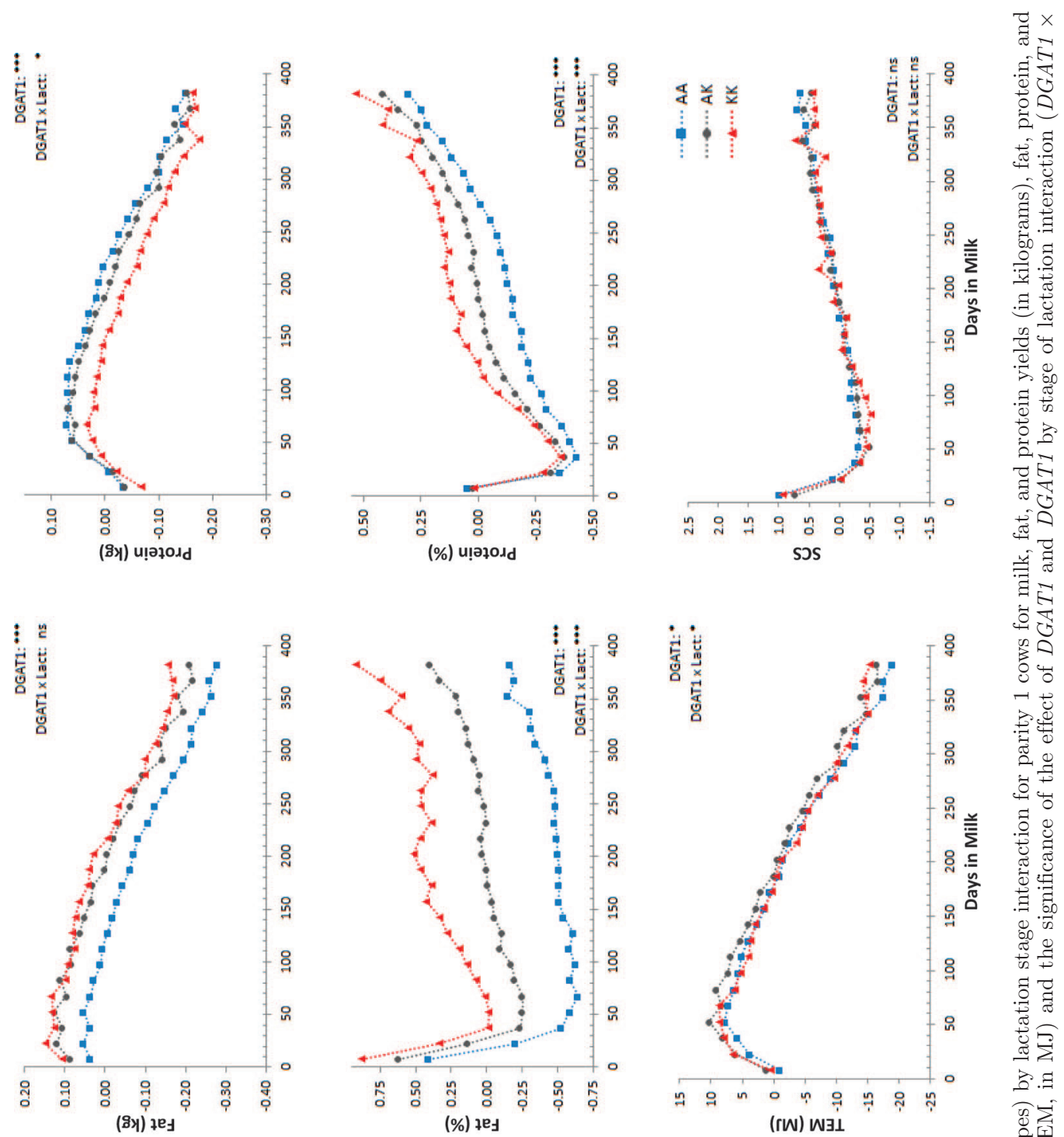

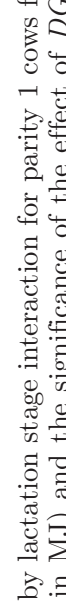
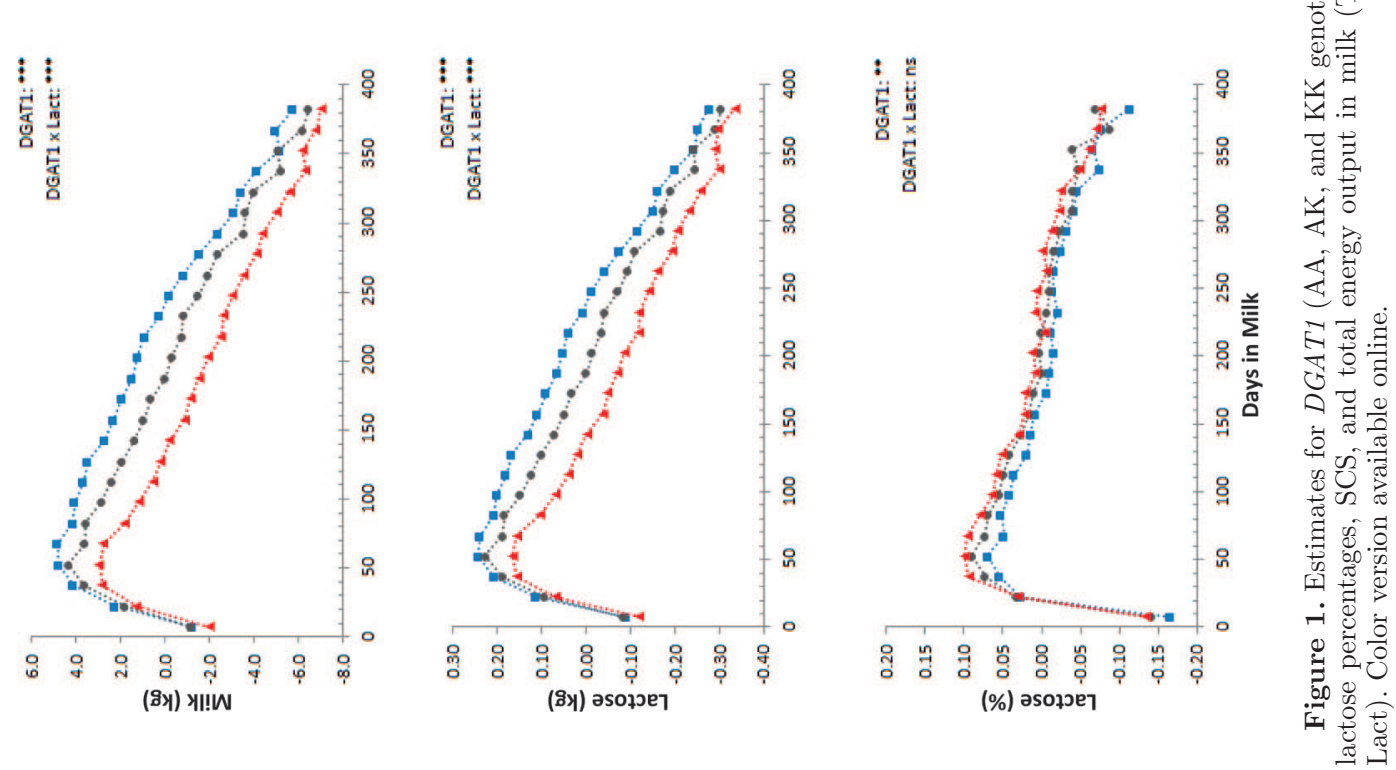

Journal of Dairy Science Vol. 98 No. 9, 2015 


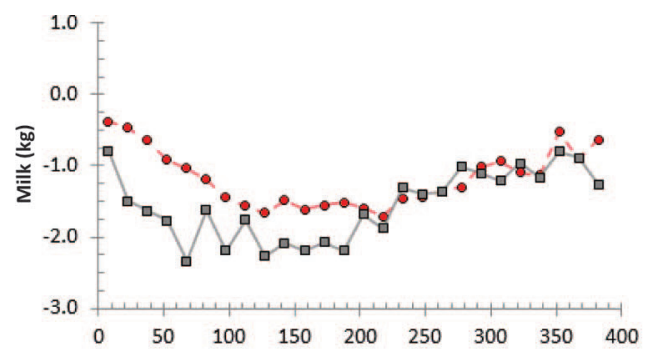

$$
\text { -•-Parity } 1
$$
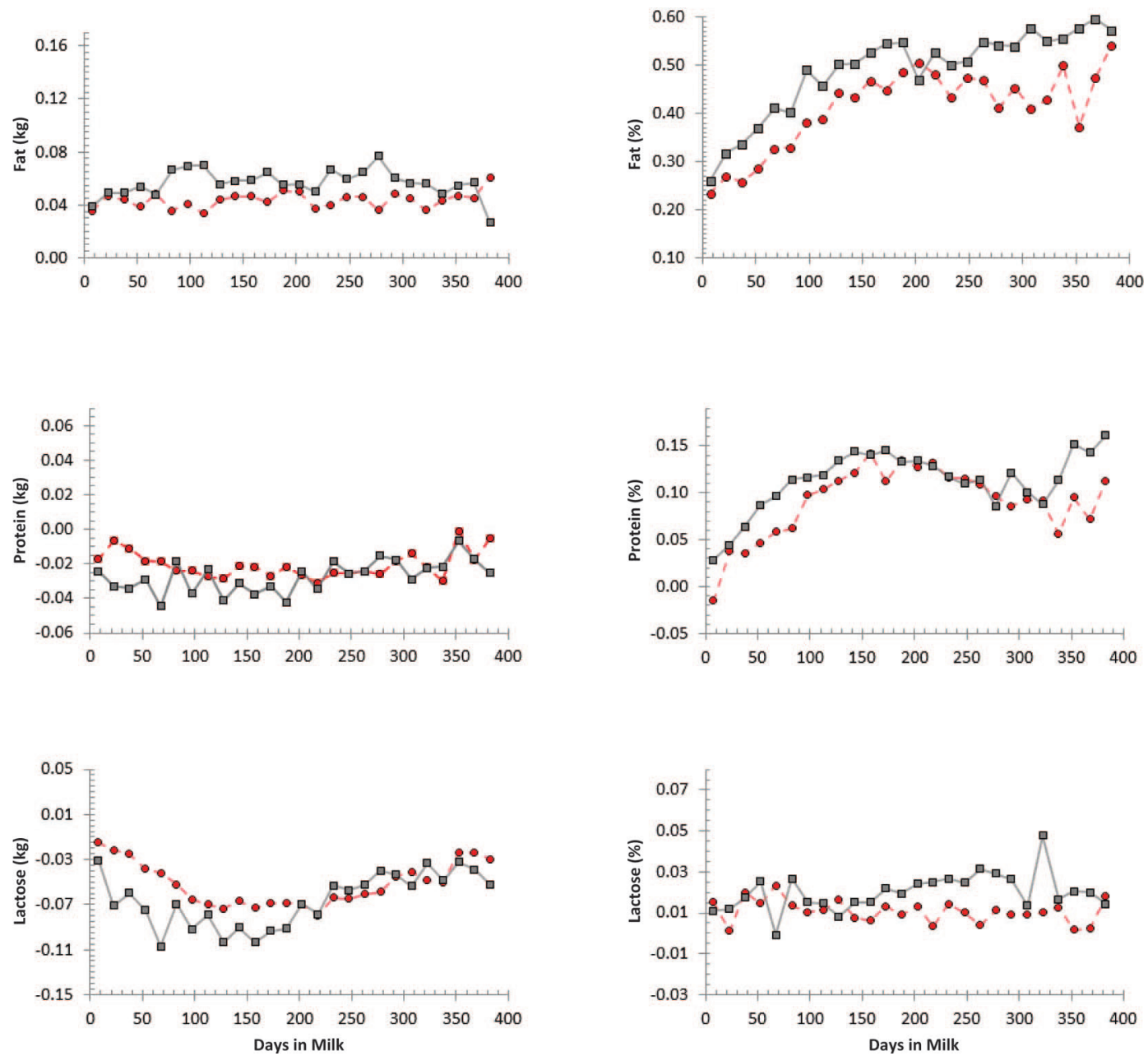

Figure 2. The additive effect $[(\mathrm{KK}-\mathrm{AA}) / 2]$ of the DGAT1 polymorphism on test-day milk production traits for different lactation stages in parity 1 and 2 . Color version available online.

similar. This illustrates the effect of scaling on DGAT1 effects.

\section{Lactose and SCS}

In our study, we also showed significant effects of $D G A T 1$ on lactose yield and content, where the $\mathrm{K}$ allele was associated with a lower lactose yield and higher lactose content. To our knowledge, estimates of DGAT1 on lactose content and yield have not been reported previously. Association of the DGAT1 K allele with higher contents of both fat and lactose is remarkable, as across species there is a strong negative relationship between lactose and fat content in milk (Fox, 2009). Lactose is the major solute in milk and osmolarity of milk is bound by biological constraints; therefore, lactose con- 
tent of milk shows very little variation (e.g., Stoop et al., 2007). To keep the osmolarity of milk constant, the effect of DGAT1 on lactose content is probably accompanied by effects on $\mathrm{Na}^{+}, \mathrm{K}^{+}$, or $\mathrm{Cl}^{-}$(i.e., other major contributors to the osmolarity of milk).

We observed that the effect of DGAT1 on lactose content increased with parity and this increase cannot be explained by scaling. This increased effect in later parities could be related to higher incidence of mastitis, as mastitis is known to be associated with lower lactose contents. However, we did not observe significant effects of DGAT1 on SCS, which is an indicator for udder health and mastitis. This is in contrast with Barbosa da Silva et al. (2010), who reported a significant effect of the DGAT1 polymorphism on SCS, and with Mach et al. (2012), who reported that the DGAT1 K232A polymorphism affected the expression of several genes involved in the immune system and associated with bovine mastitis.

\section{Total Energy Output}

Despite the dramatic effects of DGAT1 genotypes on milk yield and composition, the effect on total energy output in milk is small or absent. The only evidence we found was an increased energy output of AK cows in parity 1 . This indicates that energy requirements for milk production hardly differ between cows with different DGAT1 genotypes. Therefore, we also do not expect large differences in (negative) energy balance between these cows. This is in agreement with Banos et al. (2008), who concluded that DGAT1 K has only a marginal positive effect on cumulative effective energy balance.

Several studies have reported associations between the DGAT1 polymorphism and reproductive traits; however, results are not conclusive. Kaupe et al. (2007) reported a negative effect of the DGAT1 $\mathrm{K}$ allele on nonreturn rates, whereas Oikonomou et al. (2009) reported that the $\mathrm{K}$ allele was associated with less inseminations and higher conception rates. Based largely on the same first-parity data as used in the current study, Demeter et al. (2009) suggested a nonadditive effect of DGAT1, with AK cows having lower (6 and $4 \%)$ nonreturn rates at 28 and $56 \mathrm{~d}$ after first service. In the current study, DGAT1 AK cows had significantly higher values for TEM than AA or KK cows. This suggests that AK cows in first parity might have a higher negative energy balance than AA or KK cows. This might explain the suggestive effects of DGAT1 on nonreturn rates reported by Demeter et al. (2009). In parities 2 and 3, we did not detect an effect of DGAT1 on TEM; therefore, the effect of DGAT1 on fertility might be limited to first-parity cows.

\section{Dominance}

We detected significant dominance effects for $D G A T 1$ on fat content in all 3 parities and for fat yield in parity 1. Kuehn et al. (2007) reported a dominance effect of 0.057 for fat content, which is close to our estimate. In agreement with dominance gene action on fat yield, Strucken et al. (2011) reported significant differences in fat yield between AA and AK genotypes but a nonsignificant difference between genotype AK and KK. The dominance effects on fat content and yield are relatively small and of little practical relevance from a breeding perspective. However, from a biological perspective it is an interesting observation. Grisart et al. (2004) showed that the amount of triglycerides synthesized by the $\mathrm{K}$ allele is about 1.5 times the amount synthesized by the A allele, suggesting that the Vmax [enzymatic reaction, at maximum (saturating) substrate concentrations] of the DGAT1 K allele is higher than that of the A allele. A nonlinear relationship between the amount of enzyme and the amount of product is the basis of the classical explanation of dominance (Wright, 1934); therefore, this might provide an explanation for the observed dominance effects on fat content and fat yield.

\section{Interaction with Lactation Stage}

The results of our study show that the effect of the $D G A T 1$ polymorphism on milk yield, lactose yield, fat content, and protein content is not constant throughout lactation. These results support the basic findings by Strucken et al. (2011) and Szyda et al. (2014); however, some differences exist on how effects of DGAT1 on milk production traits change throughout lactation. Strucken et al. (2011) concluded that the characteristic DGAT1 genotypic effects occur after lactation d 40. In the current study, we observed that the lactation stage at which the maximum difference between DGAT1 genotypes is reached differed between parities and traits and ranges between d 50 and 150 in lactation. Szyda et al. (2014) concluded that effects of DGAT1 on fat and protein content increased during lactation, whereas we observed an increase in effects of DGAT1 on fat and protein content during the first $150 \mathrm{~d}$ in lactation, but later in lactation the effects stabilized for fat content and decreased for protein content. Furthermore, Szyda et al. (2014) reported that effects of DGAT1 on milk yield were constant throughout lactation, whereas we observed a strong DGAT1 by lactation stage interaction for milk yield.

The DGAT1 by lactation stage interaction is the main reason for differences between estimated DGAT1 effects reported in the current study and our earlier 
studies. Based on largely the same first-parity animals, we previously reported a difference between DGAT1 KK and AA genotypes for fat content of about $1 \%$ (Schennink et al., 2008; Duchemin et al., 2013). In the current study, the estimated difference between KK and AA genotypes in first-parity Dutch Holstein Friesians is approximately $0.8 \%$ (Table 2), which is considerably lower than the previously reported estimate. Milk samples included in the studies of Schennink et al. (2008) and Duchemin et al. (2013) were based on a single test-day record of cows between 63 and $282 \mathrm{~d}$ in lactation, whereas our study includes samples of cows in early lactation when effects of DGAT1 on fat content are smaller.

Several quantitative genetic studies showed that additive genetic variance changes throughout lactation and genetic correlations between test-day milk production records differ from unity (e.g., Druet et al., 2003; Caccamo et al., 2008). This indicates that effects of genes change during lactation, which is confirmed by gene expression studies (e.g., Bionaz and Loor, 2008; Bionaz et al., 2012; Wickramasinghe et al., 2012; Gao et al., 2013). Bionaz et al. (2012) provided evidence for differential expression of DGAT1 during lactation and indicated that significant changes in DGAT1 expression only occurred in early lactation $(<15 \mathrm{~d})$, whereas later in lactation no significant changes in DGAT1 expression were detected. In addition to differences in expression of DGAT1 throughout lactation, another DGAT enzyme, $D G A T 2$, also catalyzes the formation of triglycerides (Cases et al., 2001). Several studies have shown that DGAT1 and DGAT2 are both expressed in the bovine mammary gland and expression of both genes changes with the initiation of lactation (Bionaz and Loor, 2008; Bionaz et al., 2012; Wickramasinghe et al., 2012; Gao et al., 2013). Therefore, it seems likely that both are involved in milk FA synthesis, although little is known about their relative contribution to milk fat synthesis during lactation. Wickramasinghe et al. (2012) indicate that DGAT1 had higher expression at d 90 in lactation than at d 15 or 250, and expression of DGAT2 gradually increased from d 15 to 250. Bionaz and Loor (2008) also show differences in expression patterns during lactation for DGAT1 and DGAT2. These studies indicate that expression of DGAT1 is not constant throughout lactation and that the relative contributions of DGAT1 and DGAT2 to milk FA synthesis change during lactation. However, these expression studies are based on a limited number of sample points during lactation. Therefore, these studies do not allow us to conclude whether changes in expression of DGAT1 or differences in relative contributions of DGAT1 and DGAT2 agree with the differences in estimated DGAT1 effects on milk production traits throughout lactation and, thus, might be a cause for the DGAT1 by lactation stage interaction.

In addition to gene expression differences throughout lactation, the supply of FA to the udder also differs between early, mid-, and late lactation. The substrate available for esterification to the sn-3 position of a diacylglycerol, therefore, differs and this might have different effects on the DGAT1 A and K variants. At the initiation of lactation cows are, in general, in negative energy balance and body fat is mobilized (Garnsworthy et al., 2006).

Most of the effects of DGAT1 on milk production traits originate from the effect on water excretion (or dilution effect) and de novo FA synthesis (e.g., Schennink et al., 2008). Interestingly, we found that the additive effect of DGAT1 on fat yield is rather constant throughout lactation (Figure 2) and it seems that especially the dilution effect is responsible for the DGAT1 by lactation stage interaction. We concluded that the observed DGAT1 by lactation stage interaction might be due to a change in expression of DGAT1, an interaction of DGAT1 with other genes, or the supply of FA. The exact mechanism behind the observed effects, however, remains unclear.

\section{Implications}

We showed that the DGAT1 K232A polymorphism has major effects on milk yield and composition. However, the effect of DGAT1 on total energy excreted in milk is small. These results, therefore, do not give reason to assume that energy balance and associated metabolic and reproductive disorders are strongly affected by DGAT1. We also did not find a significant effect of DGAT1 on SCS and, therefore, do not expect any association between DGAT1 and the susceptibility to mastitis. Significant but relatively small dominance effects of DGAT1 on fat content and yield were detected, which are of little practical relevance. Furthermore, significant DGAT1 by lactation stage interactions were detected for several milk production traits. The exact mechanisms behind these changes in DGAT1 effects sizes throughout lactation remain largely unknown; however, the magnitude of the changes in effect sizes are considerable. Lund et al. (2008) indicated that analyzing 305-d milk yield in QTL analyses maybe reasonable if the gene effect is constant throughout lactation. However, when the QTL effect changes during lactation longitudinal models or analysis using only data collected during part of the lactation might substantially increase QTL detection power. For DGAT1, a higher detection power can be obtained when milk samples in 
mid- and late lactation are used. Effects of other genes also might vary throughout lactation and, therefore, estimating effects separately for parts of the lactation (e.g., early, mid-, and late lactation) or using longitudinal models is recommended.

\section{ACKNOWLEDGMENTS}

H. Bovenhuis was supported by a grant of Aarhus University Research Foundation (nr. R26 A2220). The collection of the Dutch data was part of the Dutch Milk Genomics Initiative, funded by Wageningen University (Wageningen, the Netherlands), the Dutch Dairy Association NZO (Zoetermeer, the Netherlands), Cooperative Cattle Improvement Organization CRV (Arnhem, the Netherlands), and the Dutch Technology Foundation STW (Utrecht, the Netherlands).

\section{REFERENCES}

Banos, G., J. A. Woolliams, B. W. Woodward, A. B. Forbes, and M. P. Coffey. 2008. Impact of single nucleotide polymorphisms in leptin, leptin receptor, growth hormone receptor, and diacylglycerol acyltransferase (DGAT1) gene loci on milk production, feed, and body energy traits of UK dairy cows. J. Dairy Sci. 91:3190-3200.

Barbosa da Silva, M. V. G., T. S. Sonstegard, R. M. Thallman, E. E. Connor, R. D. Schnabel, and C. P. Van Tassell. 2010. Characterization of DGAT1 allelic effects in a sample of North American Holstein cattle . Anim. Biotechnol. 21:88-99.

Berry, D. P., D. Howard, P. O'Boyle, S. Waters, J. F. Kearney, and M. McCabe. 2010. Associations between the K232A polymorphism in the diacylglycerol-O-transferase 1 (DGAT1) gene and performance in Irish Holstein-Friesian dairy cattle. Ir. J. Agric. Food Res. 49:1-9.

Bionaz, M., and J. J. Loor. 2008. Gene networks driving bovine milk fat synthesis during the lactation cycle. BMC Genomics 9:366. http://dx.doi.org/10.1186/1471-2164-9-366.

Bionaz, M., K. Periasamy, S. L. Rodriguez-Zas, W. L. Hurley, and J. J. Loor. 2012. A novel dynamic impact approach (DIA) for functional analysis of time-course omics studies: Validation using the bovine mammary transcriptome. PLoS ONE 7:e32455. http:// dx.doi.org/10.1371/journal.pone.0032455.

Caccamo, M., R. F. Veerkamp, G. de Jong, M. H. Pool, R. Petriglieri, and G. Licitra. 2008. Variance components for test-day milk, fat, and protein yield, and somatic cell score for analyzing management information. J. Dairy Sci. 91:3268-3276.

Cases, S., S. J. Stone, P. Zhou, E. Yen, B. Tow, K. D. Lardizabal, T. Voelker, and R. V. Farese Jr. 2001. Cloning of DGAT2, a second mammalian diacylglycerol acyltransferase, and related family members. J. Biol. Chem. 276:38870-38876.

Demeter, R. M., G. C. B. Schopen, A. G. J. M. Oude Lansink, M. P. M. Meuwissen, and J. A. M. van Arendonk. 2009. Effects of milk fat composition, DGAT1, and SCD1 on fertility traits in Dutch Holstein cattle. J. Dairy Sci. 92:5720-5729.

DeVita, R. J., and S. Pinto. 2013. Current status of the research and development of diacylglycerol o-acyltransferase 1 (DGAT1) inhibitors. J. Med. Chem. 56:9820-9825.

Druet, T., F. Jaffrézic, D. Boichard, and V. Ducrocq. 2003. Modeling lactation curves and estimation of genetic parameters for first lactation test-day records of French Holstein cows . J. Dairy Sci. $86: 2480-2490$.

Duchemin, S., H. Bovenhuis, W. M. Stoop, A. C. Bouwman, J. A. M. van Arendonk, and M. H. P. W. Visker. 2013. Genetic correlation between composition of bovine milk fat in winter and sum- mer, and DGAT1 and SCD1 by season interactions. J. Dairy Sci. 96:592-604.

Fox, P. 2009 Lactose: Chemistry and properties. Pages 1-15 in Advanced Dairy Chemistry, Volume 3: Lactose, Water, Salts and Minor Constituents. P. L. H. McSweeney and P. F. Fox, ed. Springer Science+Business Media LLC, New York, NY. 10.1007/978-0-38784865-5_1.

Gao, Y., X. Lin, K. Shi, Z. Yan, and Z. Wang. 2013. Bovine mammary gene expression profiling during the onset of lactation. PLoS ONE 8:e70393. http://dx.doi.org/10.1371/journal.pone.0070393.

Garnsworthy, P. C., L. L. Masson, A. L. Lock, and T. T. Mottram. 2006. Variation of milk citrate with stage of lactation and de novo fatty acid synthesis in dairy cows. J. Dairy Sci. 89:1604-1612.

Gautier, M., A. Capitan, S. Fritz, A. Eggen, D. Boichard, and T. Druet. 2007. Characterization of the DGAT1 K232A and variable number of tandem repeat polymorphisms in French dairy cattle. J. Dairy Sci. 90:2980-2988.

Gilmour, A. R., B. Gogel, B. Cullis, and R. Thompson. 2009. ASReml user guide release 3.0. VSN International Ltd., Hemel Hempstead, UK.

Grisart, B., W. Coppieters, F. Farnir, L. Karim, C. Ford, P. Berzi, N. Cambisano, M. Mni, S. Reid, P. Simon, R. Spelman, M. Georges, and R. Snell. 2002. Positional candidate cloning of a QTL in dairy cattle: Identification of a missense mutation in the bovine DGAT1 gene with major effect on milk yield and composition. Genome Res. 12:222-231.

Grisart, B., F. Farnir, L. Karim, N. Cambisano, J. J. Kim, A. Kvasz, M. Mni, P. Simon, J. M. Frere, W. Coppieters, and M. Georges. 2004. Genetic and functional confirmation of the causality of the DGAT1 K232A quantitative trait nucleotide in affecting milk yield and composition. Proc. Natl. Acad. Sci. USA 101:2398-2403.

Kaupe, B., H. Brandt, E. M. Prinzenberg, and G. Erhardt. 2007. Joint analysis of the influence of CYP11B1 and DGAT1 genetic variation on milk production, somatic cell score, conformation, reproduction and productive lifespan in German Holstein cattle. J. Anim. Sci. 85:11-21.

Kuehn, C., C. Edel, R. Weikard, and G. Thaller. 2007. Dominance and parent-of-origin effects of coding and non-coding alleles at the acylCoA-diacylglycerol-acyltransferase (DGAT1) gene on milk production traits in German Holstein cows. BMC Genet. 8:62. http://dx.doi.org/10.1186/1471-2156-8-62.

Lund, M. S., P. Sorensen, P. Madsen, and F. Jaffrezic. 2008. Detection and modelling of time-dependent QTL in animal populations. Genet. Sel. Evol. 40:177-194.

Mach, N., Y. Blum, A. Bannink, D. Causeur, M. Houee-Bigot, S. Lagarrigue, and M. A. Smits. 2012. Pleiotropic effects of polymorphism of the gene diacylglycerol-Otransferase 1 (DGAT1) in the mammary gland tissue of dairy cows. J. Dairy Sci. 95:4989-5000.

Muise, E. S., Y. Zhu, A. Verras, B. V. Karanam, J. Gorski, D. Weingarth, H. V. Lin, J. Hwa, J. R. Thompson, G. Hu, J. Liu, S. He, R. J. DeVita, D. M. Shen, and S. Pinto. 2014. Identification and characterization of sebaceous gland atrophy-sparing DGAT1 inhibitors. PLoS ONE 9:e88908.

Oikonomou, G., K. Angelopoulou, G. Arsenos, D. Zygoyiannis, and G. Banos. 2009. The effects of polymorphisms in the DGAT1, leptin and growth hormone receptor gene loci on body energy, blood metabolic and reproductive traits of Holstein cows. Anim. Genet. 40:10-17.

Schennink, A., J. M. L. Heck, H. Bovenhuis, M. H. P. W. Visker, H. J. F. Van Valenberg, and J. A. M. Van Arendonk. 2008. Milk fatty acid unsaturation: Genetic parameters and effects of stearoyl-CoA desaturase (SCD1) and Acyl CoA: Diacylglycerol acyltransferase (DGAT1). J. Dairy Sci. 91:2135-2143.

Schennink, A., W. M. Stoop, M. H. P. W. Visker, J. M. L. Heck, H. Bovenhuis, J. J. van der Poel, H. J. F. van Valenberg, and J. A. M. van Arendonk. 2007. DGAT1 underlies large genetic variation in milk-fat composition of dairy cows. Anim. Genet. 38:467-473.

Spelman, R. J., C. A. Ford, P. McElhinney, G. C. Gregory, and R. G. Snell. 2002. Characterization of the DGAT1 gene in the New Zealand dairy population. J. Dairy Sci. 85:3514-3517. 
Stoop, W. M., H. Bovenhuis, and J. A. M. van Arendonk. 2007. Genetic parameters for milk urea nitrogen in relation to milk production traits. J. Dairy Sci. 90:1981-1986.

Stoop, W. M., J. A. M. van Arendonk, J. M. L. Heck, H. J. F. van Valenberg, and H. Bovenhuis. 2008. Genetic parameters for milk fatty acids and milk production traits of Dutch Holstein Friesians. J. Dairy Sci. 91:385-394.

Strucken, E. M., D. J. de Koning, S. A. Rahmatalla, and G. A. Brockmann. 2011. Lactation curve models for estimating gene effects over a timeline. J. Dairy Sci. 94:442-449.

Szyda, J., J. Komisarek, and I. Antkowiak. 2014. Modelling effects of candidate genes on complex traits as variables over time. Anim. Genet. 45:322-328

Thaller, G., W. Krämer, A. Winter, B. Kaupe, G. Erhardt, and R. Fries. 2003. Effects of DGAT1 variants on milk production traits in German cattle breeds. J. Anim. Sci. 81:1911-1918.
Tyrrell, H. F., and J. T. Reid. 1965. Prediction of the energy value of cow's milk. J. Dairy Sci. 48:1215-1223.

Weller, J. I., M. Golik, E. Seroussi, E. Ezra, and M. Ron. 2003. Population-wide analysis of a QTL affecting milk-fat production in the Israeli Holstein population. J. Dairy Sci. 86:2219-2227.

Wickramasinghe, S., G. Rincon, A. Islas-Trejo, and J. F. Medrano. 2012. Transcriptional profiling of bovine milk using RNA sequencing. BMC Genomics 13:45.

Winter, A., W. Kramer, F. A. Werner, S. Kollers, S. Kata, G. Durstewitz, J. Buitkamp, J. E. Womack, G. Thaller, and R. Fries. 2002. Association of a lysine-232/alanine polymorphism in a bovine gene encoding acyl-CoA:diacylglycerol acyltransferase (DGAT1) with variation at a quantitative trait locus for milk fat content. Proc. Natl. Acad. Sci. USA 99:9300-9305.

Wright, S. 1934. Physiological and evolutionary theories of dominance. Am. Nat. 68: 24-53. 